\title{
The JOSHA Demetrios Project: - Slovensky
}

\section{Authors: Hana Andrlová}

Submitted: $\quad$ 1. November 2017

Published: $\quad$ 2. November 2017

Volume: 4

Issue: $\quad 5$

Affiliation: Universitätsklinikum Freiburg, Department of Hematology and Oncology and Stem Cell Transplantation

\section{Languages: Slovak}

Keywords: $\quad$ Textbook, Monograph, Books as Open Online Content (BOOC), Demetrios of Phaleron, Alexandrina Library, Language: Slovak Učebnica, monografia, knihy ako otvorený online obsah (BOOC), Demetrios z Phaleron, knižnica Alexandrina, slovenský

DOI: $\quad$ 10.17160/josha.4.5.351 
Slovensky 10.2017

\title{
Medzinárodná akadémia vedy, humanitných štúdií a umenia
}

\author{
IASHA e.V. Freiburg, Nemecko
}

\author{
JOSHA Demetrios Projekt
}

Knihy a články $v$ akomkol'vek jazyku

Knihy ako online obsah s otvoreným prístupom (Boks as Open Online Content BOOC)

S júlovým číslom 2017, JOSHA začína Łvv. Projekt Demetrios. Za patróna nášho projektu sme si vybrali Demetriosa z Phaleronu, študenta Theophrasta a pravdepodobne aj Aristotela. Demetrios sa podiel'al na založení starovekej Alexandrijskej knižnice, pravdepodobne najväčšej a najvýznamnejšej knižnice v antickom svete, poknývajúcej všetky aspekty vedy, humanitných štúdií a umenia v mnohých jazykoch.

Naším ciel'om je otvorenie JOSHA ako široko dostupnej knižnice s otvoreným prístupom pre všetky krajiny a všetky svetové jazyky.

Prvotný zámer JOSHA je publikovanie a poskytovanie otvoreného prístupu ku knihám z akejkolvek oblasti vedy, humanitných štúdií a umenia študentom a čitatelom po celom svete. JOSHA plánuje publikovat' knihy v akomkolvek jazyku po adekvátnom odbomom zhodnotení expertov v danej oblasti so znalost'ou daného jazyka. Predstavenstvo IASHA a editori JOSHA cítia urgentnú potrebu poskytovat prístup k publikovaným materiálom predovšetkým študentom a vedcom z krajín so stredným a nízkym prijmom, kde si väčšina študentov nemôže dovolit' knihy v papierovom formáte. Náš ciel' je povzbudzovat' autorov a čitatel'ov, aby nám predkladali svoje knihy a články určené k publikácii v JOSHA bez nároku na honorár a aby nás upozorňovali na oblasti ktorým je potreba venovat' zvýšený záujem.

Tento projekt sme začali učebnicami architektúry, ktorých autorom je profesor Bujar z Kosova, a ktoré sú písané v albánčine.

Podpora tohto projektu je $v$ špeciálnom záujme všetkých členov neprofitovej Medzinárodnej akadémie vied, humanitných štúdií a umenia (IASHA e.V.) vo Freiburgu, ktorá je vydávatel'om JOSHA. Túto dôležitú iniciatívu môžete podporit' aj Vy tým, že sa pridáte k filantropickému združeniu IASHA e.V. (https://iasha.org), alebo finančne podporíte toto združenie. 
„Vediet', že aspoň jedno smutné srdce bilo o čosi menej ustrašene... Tomu sa povie úspech." (Ralph Waldo Emerson, 1803 - 1882).

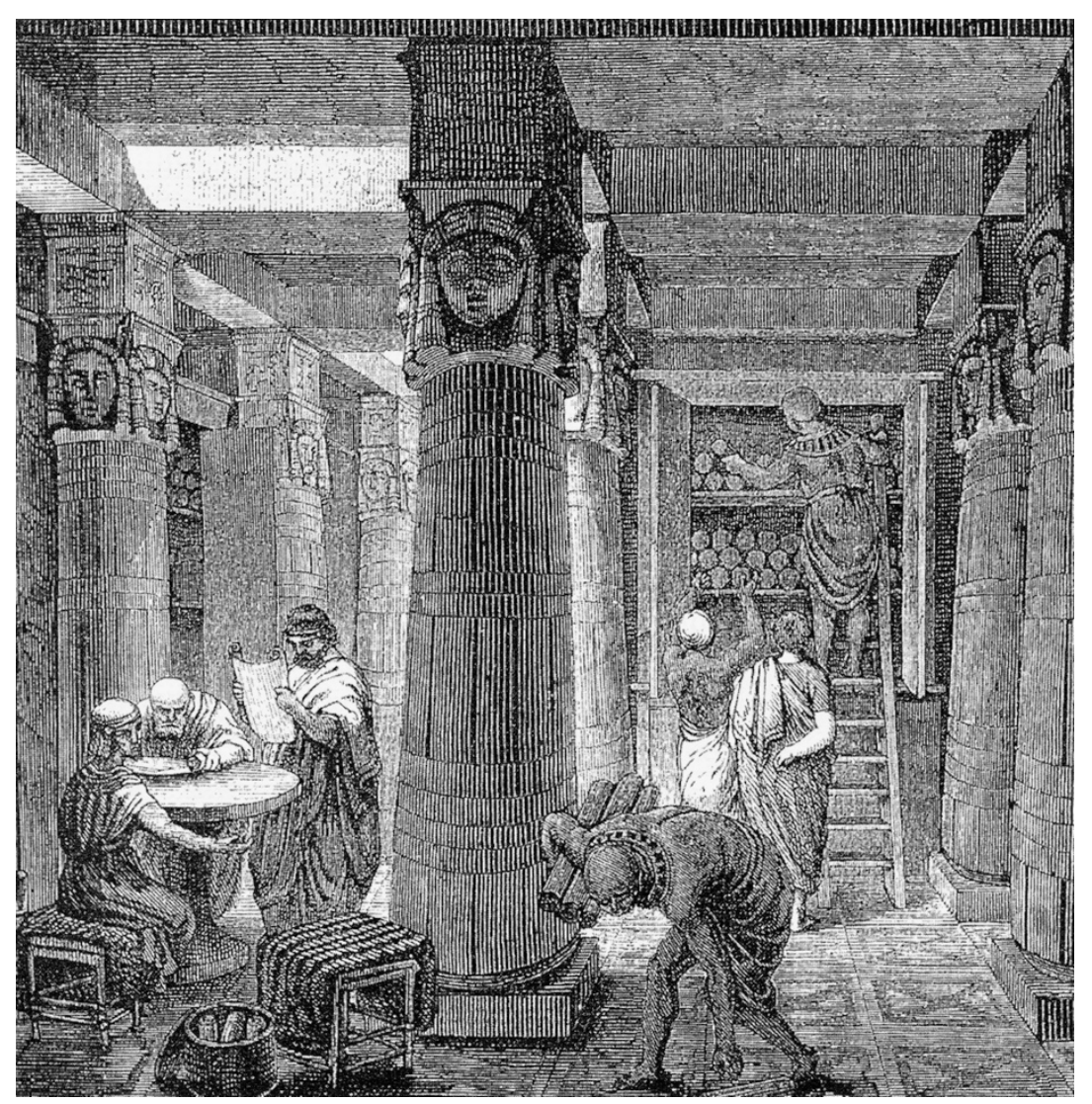

(Text under the picture): Obraz O.Von Corvena, zdroj Tolzmann, Don Heinrich, Alfred Hessel a Reuben Peiss. Pamät' ludstva. New Castle, DE: Oak Knoll Press, 2001, verejná doména https://commons.wikimedia.org/A

\section{O JOSHA}

Online Žurnál o vede, humanitných štúdiách a umení JOSHA s otvoreným prístupom je nová internetová platforma pre prístup k širokej škále dôležitých objavov a kreatívnych nápadov v oblasti vedy, humanitných štúdií a umenia. JOSHA je žurnálom Medzinárodnej vedeckej akadémie IASHA e.V. vo Freiburgu v Nemecku.

My v JOSHA veríme, že „vedomosti, ktoré nie sú šírené d’alej, sú premrhané vedomosti". Preto sme založili náš žurnál s otvoreným prístupom a bez poplatkov, obsahujúci publikácie v rozličných oblastiach vedy, humanitných štúdií a umenia, ktorý zároveň vyzýva a podnecuje študentov, vedcov a umelcov k zverejneniu svojich vedomostí. 
Doteraz (August 2017) boli publikované 4 vydania, 16 čísel a viac ako 120 článkov. Naša aktuálna sledovanost' dosiahla mesačne viac ako 190000 zhliadnutí a viac ako 150000 stiahnutí.

Rámec našich autorov a čitatel'ov začína magisterskými a PhD študentami a končí umelcami, či dokonca laureátmi Nobelovej ceny.

JOSHA je dostupná cez našu webovú stránku www.josha-journal.org a cez sociálne siete Facebook a Linkedln.

JOSHA môžete nájst' aj v ROAD (Directory of Open Access Scholarly Resources: Vedenie študentských zdrojov s otvoreným prístupom), ejournal.org a Scilit.

Publikačný softvér JOSHA vol vyvinutý JOSHA GmbH Software a spadá pod licenciu Medzinárodnej vedeckej akadémie IASHA e.V. 